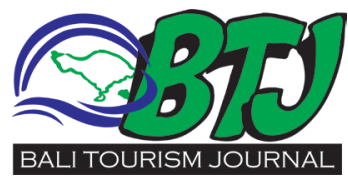

\title{
Fermented Cocoa Expansion : From Jembrana to The World
}

\author{
Ida Bagus Komang Surya Werdiyasa
}

* Ida Parida Digital Creator;

gusmang848@gmail.com

Received: 2021-05-09

Accepted: 2021-07-12

Published: 2021-08-01

\section{ABSTRACT}

At the beginning of September 2021, Jembrana fermented cocoa product successfully expanded its export market to Japan. In terms of international trade, Indonesia also ranks third with a share of $14.6 \%$ of the total 2.96 million tons of world cocoa bean exports in 2010, while the first and second ranks are still occupied by after Côte d'Ivoire and Nigeria with a share of 26 each $7 \%$ and $18.6 \%$. ${ }^{3}$ From the data, Indonesia's role in the world as a cocoa producer is strategic. ${ }^{4}$ Although known as the third-largest cocoa exporter, before 2013, Indonesian cocoa entrepreneurs were occasionally facing various classic problems. The obstacles were due to poor products and the minor Government support. Currently, With the industrial downstream policies, the cocoa industry's development is heading in a better direction. Further, after being certified by the International certification program, UTZ, Jembrana cocoa product reached a broader market. Jembrana cocoa beans have been known internationally for their unique taste. The fermentation process and post-farm handling become vital in preserving the beans' finest quality.

Keywords: Jembrana Cocoa, Industry, Fermented.

Cite This Article: Werdiyasa, I.B.K.S. 2021. Fermented Cocoa Expansion : From Jembrana to The World. Bali Tourism Journal 5(2): 23-26. DOI: 10.36675/btj.v5i2.55

\section{BACKGROUND}

At the beginning of September 2021, Jembrana fermented cocoa product successfully expanded its export market to Japan. Cocoa products are highlydemanded ingredients in several food and beverages. ${ }^{1}$ Since 1990, the area for cocoa plantation and production in Indonesia has dramatically increased. The significant development of cocoa farming put Indonesia as the fourth largest cocoa producer globally after Côte d'Ivoire, Ghana and Nigeria in 2008. Then, in 2010 Indonesia's position was ranked third, producing more than $15 \%$ of the world's Cocoa. ${ }^{2}$ In terms of international trade, Indonesia also ranks third with a share of $14.6 \%$ of the total 2.96 million tons of world cocoa bean exports in 2010, while the first and second ranks are still occupied by after Côte d'Ivoire and Nigeria with a share of 26 each $7 \%$ and $18.6 \% .^{3}$ From the data, Indonesia's role in the world as a cocoa producer is strategic. ${ }^{4}$

These leading plantation commodities play an essential role in Indonesian economic growth. The high demand for Cocoa encourages job creation, source of income and foreign exchange commodities for the country. In addition, Cocoa also plays a role in encouraging regional development and agro-industry development. ${ }^{5}$ The success of Jembrana cocoa products in penetrating the East Asian market is a new thing. Prior to 2010, Indonesian cocoa products had low competitiveness. Especially in Jembrana, there were a decade of hard times, where cocoa farmers left the industry due to uncertain income.

\section{A Decade of Improvement}

Although known as the third-largest cocoa exporter, Indonesian cocoa entrepreneurs were occasionally facing various classic problems. The problems were low farm yields, pests, diseases, poor post-production quality due to untrained human resources, unfermented Cocoa and impured products. Meanwhile, institutional support perspective, downstream product development support was highly neglected. Indonesia's cocoa exports were raw, unprocessed, and thus prone to the discounted price. The other problems were export levies and value-added taxes that significantly inflicted the business' profit.

With the current industrial downstream policies, the development of the cocoa industry is heading to a better future. The cocoa exporter is required to do domestic processing by adding value to the raw material products. On the other hand, some efforts such as strengthening the industrial structures, providing employment opportunities, attracting investors, and providing a prospectus business opportunity in Indonesia have elevated the business to a higher level. By implementing this downstream policy, the Government also gains more benefits due to the cost-efficiency. It supports Indonesian cocoa products to be competitive in terms of price. Other results can be seen from declining figures of unprocessed cocoa bean exports but did not affect the overall cocoa exports. Various cocoa plantation and processing companies resumed their business, increasing employment absorption and a better product. ${ }^{7}$

Cocoa plants are relatively easy to grow in Indonesia, especially in Jembrana, Bali. 


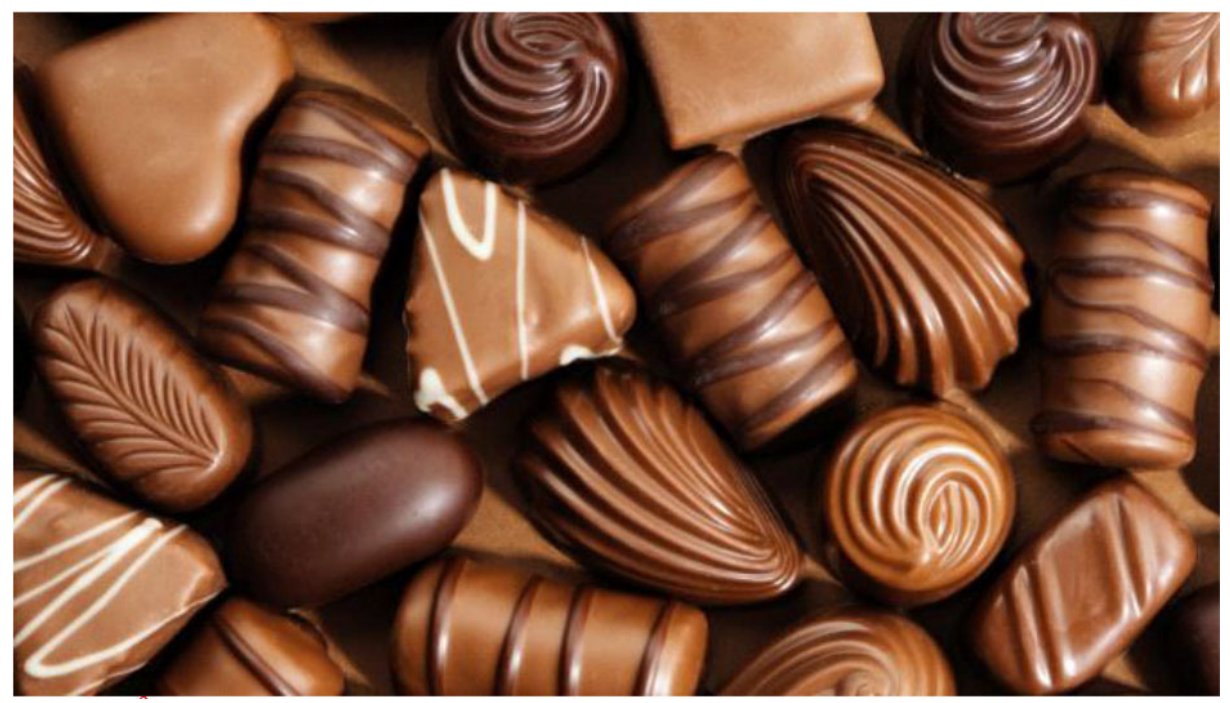

Figure 1. ${ }^{6}$ Milk Chocolate, one of the most favorite processed Cocoa product.

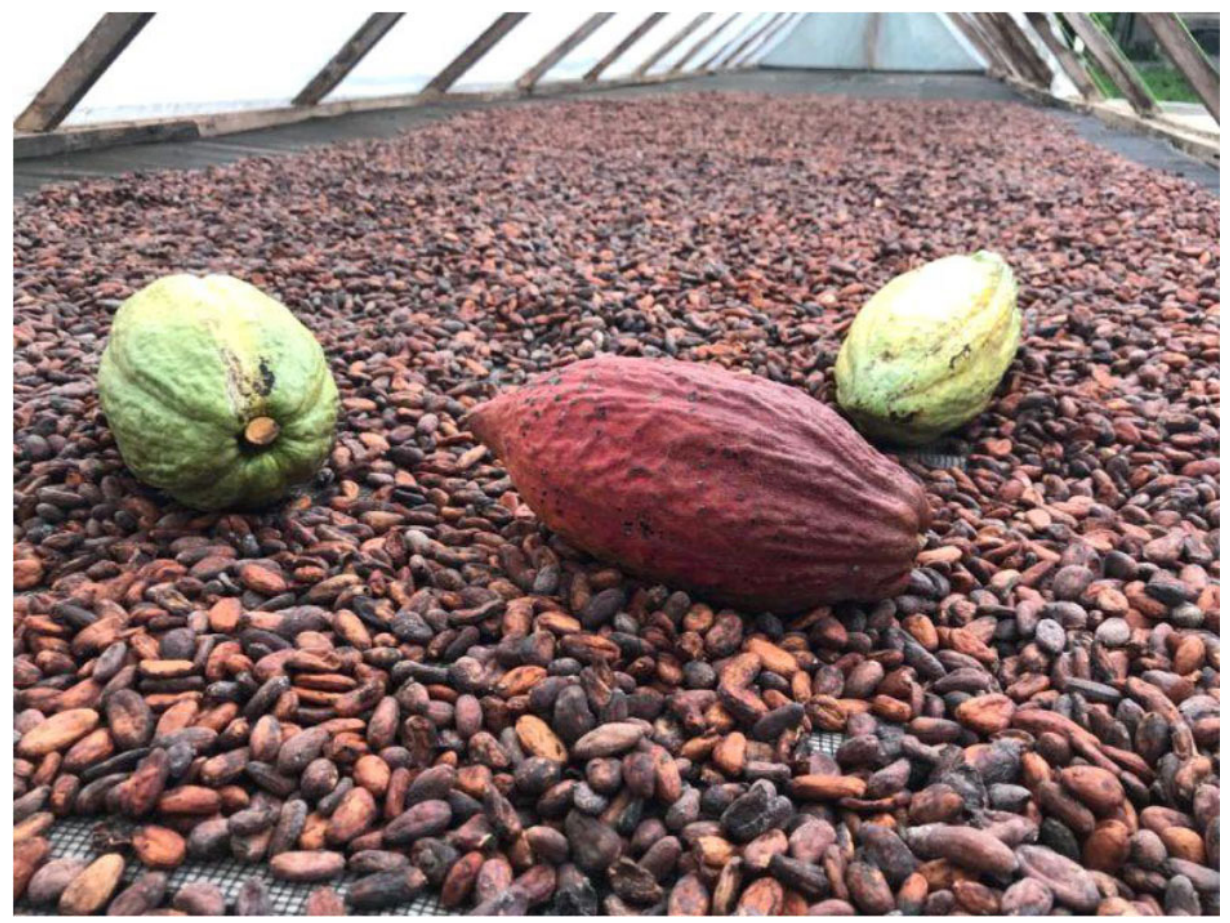

Figure $2 .{ }^{10}$ After the fermentation process, the beans would be dried under sunlight.

However, its domestic consumption is lower than the foreign export figure. To shift the domestic industry mindset to start selling a fermented cocoa product was a great challenge. Nevertheless, in Jembrana, Bali, the farmers agree to carry out postharvest processing through fermentation techniques. They realized that improving the cocoa beans quality would give their product a better price in the market. The competitiveness product was achieved after the local farmer started to increase attention to the environment, social and economy with a sustainable agricultural approach. Besides, through their village-based institution, the farmer participated in an international certification program of sustainable agriculture. It had a positive impact by subconsciously controlling the farmer's effort to strive for a good quality product and secure their bargaining position in the domestic and foreign market. ${ }^{8}$

One of the internationally acclaimed labels and certification programs for sustainable agriculture is UTZ. For the province of Bali, the Koperasi Kerta Semana Samiya (KKSS) in Jembrana Regency is one of the certified cocoa companies. KSS is a village-based institution engaged in cocoa management and marketing in Jembrana Regency. According to the data from the quarantine system, IQFAST Barantan, the export volume of Jembrana cocoa beans has increased in line with its quality recognition by the international market. In 2020, the export volume of cocoa beans reached 26 tons. This figure increased significantly compared to the previous year, which was only 7.5 tons.

\section{Pre and Post Harvest Handling}

Jembarana cocoa beans lead the quality over Indonesia regions. The planting and postharvest processes influence its unique taste. The plant is meticulously maintained, organically treated without any chemical substances, starting when the seeds touch the soil. As a substitute for pesticides, farmers utilize $M O L$, a biopesticide made from organic waste. It is a cheap, safe, easy to make, and environmentally friendly biopesticide that the local cocoa farmers widely known. In addition, to reduce potential pests, MOL boosts the plant's vegetative growth, making the plant grow more leaves. The MOL utilization also helps to improve soil physical and chemical properties, which plays a vital factor in cocoa plant growth. A study reported, MOL is an effective insecticide against Planococcus minor. ${ }^{1}$

For postharvest processing, the farmers use fermentation techniques on cocoa beans. It starts from planting phases until the cocoa fruits are ready to be picked. After picking, the cocoa pods are split in half to collect their beans. The beans are then placed into a fermentation box for six days. The cocoa beans would reach a temperature of 48-50 degrees Celsius naturally after six days. After the fermentation process, the beans would be dried under sunlight. The Cocoa beans that have undergone this process would be packed, then be sold to buyers. ${ }^{9}$

Although it takes longer to prepare fermented beans, the fermentation technique produces Cocoa with a distinctive aroma. This most refined quality product has travelled around the world. Besides Japan, the Jembrana cocoa 


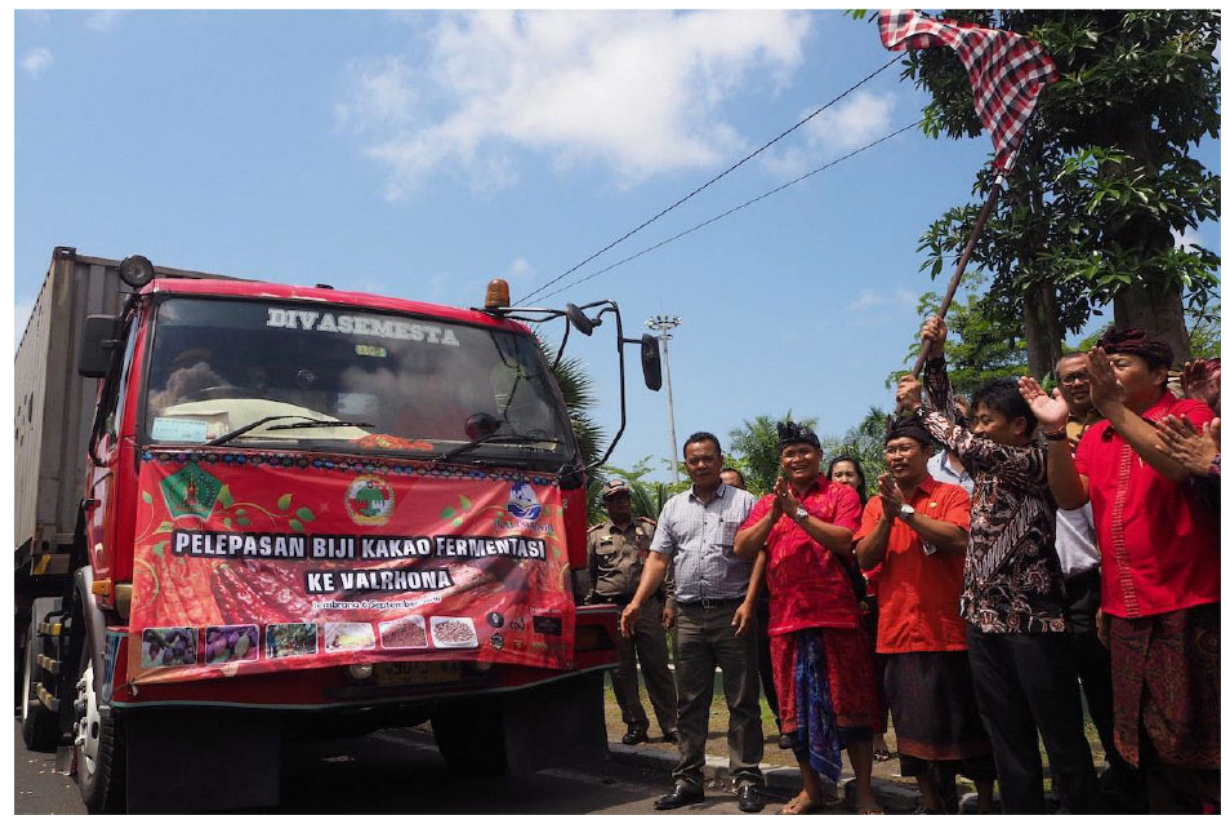

Figure $3 .{ }^{13}$ Besides Japan, the Jembrana cocoa beans have penetrated Germany, the United States, Austria, Portugal, Morocco, Saudi Arabia, Singapore, South Korea, Switzerland and Belgium.

beans have penetrated Germany, the United States, Austria, Portugal, Morocco, Saudi Arabia, Singapore, South Korea, Switzerland and Belgium. ${ }^{11}$

Governor of Bali, I Wayan Koster praised the extraordinary potential of Jembrana cocoa. He even admitted it as the best in Bali. Through institutional supports, the cocoa industry development would be run smoothly from upstream to downstream. The potential must be maximized as an added economic value for the people of Jembrana. Further, Koster expected Jembrana youth would love to continue and even excelled the current cocoa industry without neglecting their local wisdom, such as Jegog and Mekepung. ${ }^{12}$

\section{COVID - 19 Pandemic Impact on the Industry}

Amid the COVID-19 pandemic, Jembrana farmers were able to reach tens kilograms yields per month. Although it must be admitted, production has decreased drastically due to minimal demand. The chairman of KKSS I Ketut Wiadnyana admitted Agricultular Quarantine Office plays a vital role in helping the export procedure. The Agricultural Quarantine Agency assisted in completing the export requirements; thus, quarantine certification services can be accelerated. $\mathrm{He}$ and the other farmers are grateful for the office's assistance in exporting their cocoa beans. The agricultural products are always well and smoothly received in destination countries due to the well-met export requirements. ${ }^{14}$

Meanwhile, the Head of the Indonesian Agricultural Quarantine Agency, Ali Jamil, said that Indonesia is the thirdlargest Cocoa producing country in the world. However, large quantity does not necessarily have good quality if postharvest processing is not following the standards of the destination country. He explained that the commodity from the plantation subsector is one of the focuses of commodities included in the program to increase agricultural exports. It is programmed as the Triple Agricultural Exports Movement (Gratieks). Nationally, the total export value reached $\mathrm{Rp} 336.8$ billion in 2019 . The figure increased significantly to Rp 831.9 billion in $2020 .{ }^{15}$ Based on the latest data (Indonesia Quarantine Full Automation System/IQFAS), cocoa commodity exports from Jembrana have reached 5.3 tons. ${ }^{16}$

\section{CONCLUSION}

Although known as the third-largest cocoa entrepreneurs were occasionally facing exporter, before 2013, Indonesian cocoa various classic problems. The obstacles were due to poor products and the minor Government support. Currently, With the industrial downstream policies, the cocoa industry's development is heading in a better direction. The cocoa exporter is required to do domestic processing by adding value to the raw material products. On the other hand, some efforts such as strengthening the industrial structures, providing employment opportunities, attracting investors, and providing a prospectus business opportunity in Indonesia have elevated the business to a better level.

Further, after being certified by the International certification program, UTZ, Jembrana cocoa product reached a broader market. Jembrana cocoa beans have been known internationally for their unique taste. The fermentation process and postfarm handling become vital in preserving the beans' finest quality. Recently the cocoa beans have been marketed to Japan, Germany, the United States, Austria, Portugal, Morocco, Saudi Arabia, Singapore, South Korea, Switzerland and Belgium.

\section{REFERENCES}

1. Naningsi N. Penggunaan Mol Hijau Pada Tanaman Kakao Di Desa Dangintukadaya, Kecamatan Jembrana, Kabupaten Jembrana. Jurnal Ilmiah Vastuwidya. 2019;2(2):16-9.

2. International Cocoa Organization [ICCO]. 2011. ICCO quarterly bulletin of cocoa statistics. Vol. XXXVII, No. 2, Cocoa Year 2010/2011. ICCO, London, UK.

3. International Trade Centre [Intracen]. 2011. Trade map-International trade statistics: Cocoa and cocoa preparations. http://www.trademap. org/tradestat/Country SelProduct TS.aspx. Diakses tanggal 30 Desember 2011

4. Hasibuan AM, Nurmalina R, Wahyudi A. Analisis kinerja dan daya saing perdagangan biji kakao dan produk kakao olahan Indonesia di pasar internasional. Jurnal tanaman industri dan penyegar. 2012 Mar 30;3(1):57-70.

5. Maswadi. 2011. Agribisnis Kakao dan Produk Olahannya Berkaitan dengan Kebijakatan Tarif Pajak di Indonesia. J. Perkebunan \& Lahan Tropika. 1: 23-30.

6. Image from Article ' 10 Negara Penghasil Cokelat Terbaik' by Peggy. Pegipegi[dot]com. 2015. Available at URL: https://www.pegipegi. com/travel/10-negara-penghasil-cokelat$\underline{\text { terbaik/ }}$

7. Hadinata S, Marianti MM. Analisis Dampak Hilirisasi Industri Kakao di Indonesia. Jurnal Akuntansi. 2020 May 17;12(1):99-108.

8. Ambarawati GA, Dewi IA. Peranan Program Sertifikat UTZ Terhadap Peningkatan Produksi 
dan Pendapatan Petani Kakao Di Kabupaten Jembrana Provinsi Bali. Agrisocionomics: Jurnal Sosial Ekonomi Pertanian. 2019 Nov 30;3(2):68-76.

9. IMA Ismayana. Petani Kakao di Jembrana Hasilkan 50 Kilogram Biji Cokelat Per Bulan, Wirahadi: Cukuplah untuk Makan. TribunBali[dot]com. 2021. Available at URL: https:// bali.tribunnews.com/2021/09/30/petanikakao-di-jembrana-hasilkan-50-kilogram-bijicokelat-per-bulan-wirahadi-cukuplah-untukmakan?page=all.

10. Image from article 'Kisah Kakao Jembrana yang Mendunia dan "Cocoa Exellence 2017"'. Energyworld[dot]co[dot]id. 2017. Available at URL: https://energyworld.co.id/2017/11/22/ kisah-kakao-jembrana-yang-mendunia-dancocoa-exellence-2017/

11. NPE Wiratmini. Kakao Jembrana Tembus Pasar Jepang. Bisnis Bali. 2021.
Available at URL: https://bali.bisnis.com/ read/20210901/538/1436803/kakao-jembranatembus-pasar-jepang.

12. Press Release Jembrana Public relations. Koster Akui Keunggulan Kakao Jembrana Terbaik di Bali. 2021. Available from URL: https://www.news.beritabali.com/ read/2021/06/22/202106220031/koster-akuikeunggulan-kakao-jembrana-terbaik-di-bali

13. Image by Anton Muhajir/Mongabay 'Dirjen Perkebunan Kementerian Pertanian melepas ekspor kakao fermentasi di Negara, Jembrana, Bali, Sabtu (6/9/2018). Dekopin. 2018. Available from URL: https://www.dekopin.co/koperasikakao-jembrana-menembus-pasar-dunia/

14. D Divianta. Perjalanan Biji Kakao Fermentasi Jembrana Sampai Mendunia. Liputan 6. 2021. Available at URL: https://www.liputan6.com/ regional/read/4497683/perjalanan-biji-kakaofermentasi-jembrana-sampai-mendunia

15. M kadafi. Kualitas Semakin Diakui, Ekspor Kakao Jembrana Terus Meningkat. Merdeka. 2021. Available at URL: https://www.merdeka. com/peristiwa/kualitas-semakin-diakuiekspor-kakao-jembrana-terus-meningkat.html

16. Kakao Jembrana Tembus 10 Negara. Nusa Bali. 2021. Available at URL: https://www.nusabali. com/berita/101598/kakao-jembrana-tembus$\underline{10 \text {-negara }}$

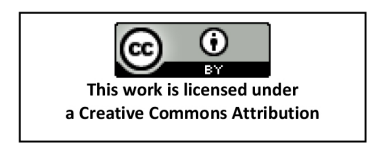

